\title{
Civility, patriotism and performance: Cato and the Irish history play
}

\author{
David O’Shaughnessy
}

Recent scholarship has underscored history writing as central to the culture of the eighteenth century and as a key mode of Enlightenment thought and practice in both Britain and Ireland. ${ }^{1}$ British elites, conscious of their own historiographical failings, looked uneasily on the French exemplar national histories which sparked a patriotic urging to match their Continental competitors. ${ }^{2}$ Writ properly, it was suggested, history could also lead to a more rational patriotic attachment to one's own country, one enriched by a recognition of other nations in the spirit of Enlightenment. ${ }^{3}$ The proper framing and writing of national history (understood in the main as that which adhered to rigorous neoclassical values) also conveyed a country's teleological progressiveness, its emergence from barbarity towards modernity, civilization and associated institutional norms. The form and content of a well written national history—encompassing inter alia a decorous tone, idealized characters, moral didacticism - mirrored each other, allowing a reader to assess their own civility as well as that of the country and its people in question. Enlightenment is a term with a myriad of

My sincere thanks to Emily Anderson and David Taylor for their helpful comments on an earlier version of this essay. This chapter has received funding from the European Union's 2020 research and innovation programme under the Marie Sklowdowska-Curie grant agreement No 745896.

${ }^{1}$ Noelle Gallagher, Historical Literatures: Writing about the Past in England, 1660-1740 (Manchester University Press, 2012); Ruth Mack, Literary Historicity: Literature and Historical Experience in Eighteenth-Century Britain (Stanford University Press, 2009); and, Karen O'Brien, Narratives of Enlightenment: Cosmopolitan History from Voltaire to Gibbon (Cambridge University Press, 1997). On Ireland and history writing, see Clare O'Halloran, Golden Ages and Barbarous Nations: Antiquarian Debate and Cultural Politics in Ireland, c.1750-1800 (Cork University Press and Notre Dame Press, 2005), and Charles O'Conor of Ballinagare: Life and Works, ed. Luke Gibbons and Kieran O'Conor (Dublin: Four Courts Press, 2015).

${ }^{2}$ Gallagher, Historical Literatures, 1-2.

${ }^{3}$ O'Brien, Narratives of Enlightenment, 15. 
associated values; this essay looks at the genre of history plays while keeping these notions of patriotism and civilization foremost in mind.

This chapter argues for the greater relevance of the history play to our understanding of theatrical culture of the period. It is surprising perhaps that history plays of the period have remained the poor cousins of comedy and tragedy, the two genres that remain the focus of critical attention. ${ }^{4}$ That the first three plays refused a licence under the Stage Licensing Act were history plays should alert us to the significance of this neglected genre. That they were written respectively by an Irishman, a Scotsman, and an Englishman indicates the centrality of the history play to ideas of nationhood in the era of Enlightenment. ${ }^{5}$ The affective force of historical drama, the genre's cultural capital as well as its capacity for political provocation, particularly in the wake of Joseph Addison's Cato (1713), makes this unsurprising. We would benefit then to bring history plays more into the conversation of eighteenth-century theatre, thus complicating the existing canon of British theatre, both synchronically and diachronically.

The essay freely concedes that further work will be required in terms of theorizing the history play, not least, for example, in terms of distinguishing it - to the extent that it can be-from tragedy. The Irish case-study discussed here simply shows how consideration of the neglected history play can bear critical fruit; it provides the justification for the pursuit of such a broader study, a point I will return to in my conclusion. The Irish example is well

\footnotetext{
${ }^{4}$ Paulina Kewes has also lamented the sidelining of the history play's transformation of history writing from the sixteenth to the eighteenth century. Paulina Kewes, 'History and its uses' in The Uses of History in Early Modern England, ed. Kewes (San Marino, CA: Huntington Library Press, 2006), 4-5. But see some recent work on Romantic period history plays in Staging History: 1780-1840, ed. Michael Burden, Wendy Heller, Jonathan Hicks and Ellen Lockhard (Oxford: Bodleian Library, 2016).

${ }^{5}$ After Brooke's Gustavus Vasa, James Thomson's Edward and Eleonora (1739) and William Paterson's Arminius (1739) were subsequently refused performance licences. We might also note, given our interest in Cato, that Arminius tells the story of a great German hero who resisted Caesar.
} 
chosen: as the introduction to this volume details, historiography and patriotism are closely linked in Irish writing at a time when Irish writers and actors were in the ascendant in London. If theatre plays a part then in an Irish Enlightenment, we are surely obligated to consider how playwrights and actors treated the history play genre. And if, as Paddy Bullard and Michael Brown have argued, rhetoric is central to the discourse of Irish patriotism, then we must put Irish dramatists and actors' command or otherwise of verse tragedy under scrutiny. ${ }^{6}$ As a rich site of discursive confluence of patriotism, rhetoric, and historiography, the history play demands our attention when considering the Irish Enlightenment. To pick up, for instance, Brown's oppositional threads of empiricism and rationality, we note they can co-exist happily in the history play: Irish actors delivering complex speeches in verse challenges stereotypes of clumsy Irish bulls (thus offering empirical evidence of ethnic civility) and Irish dramatists displaying mastery of a 'high' literary genre disputes notions of Irish cultural barbarism (thus offering evidence of rational thought). History plays were a potent political genre, capable of casting light on the present state of affairs and gesturing towards a different kind of future. For Irish writers, the genre had a particular attraction: not only could the force of historical resonance be brought to bear on a particular issue but the history play provided a forum for a writer to display not only a collective ethnic claim to civility but also individual flair and literary acumen as well. The history play that evoked patriot sentiment allowed the Irish to demonstrate their capacity for self-regulation and political autonomy in cadenced and rational speeches, trumpeting the values-liberty, love of country, reason etc - that Britain held dear. The history play also provided a clear generic leap away from the uncouth Stage Irishman such as Teague from Robert Howard's The Committee (1665), enhanced by the growing affective force of Irish actors working in London who became increasingly influential through the century. James Quin, Dennis

\footnotetext{
${ }^{6}$ See introduction, $17-19$.
} 
Delane, and Charles Macklin, as we shall see, were pivotal but so too were Catherine Clive and Margaret Woffington, amongst others listed in the introduction to this volume.

Tracing Irish echoes of Cato, arguably the most important political play of the century, will be central to my argument. How Irish dramatists and actors responded to this idealized representation of British values is an illuminating barometer of their Enlightenment ambitions and the reception of those same ambitions. I have argued elsewhere that Cato was an important influence on Charles Macklin's The Man of the World (1781) in an essay that made the case for Macklin as an Enlightenment figure. ${ }^{7}$ Here, I wish to first deepen the Irish association with Addison's historical tragedy before working through three earlier examples of Cato-inflected Irish dramas: William Philips's Hibernia Freed (1722); Henry Brooke's Gustavus Vasa (1739), and Charles Macklin's King Henry the VII; or, The Popish Impostor (1746). Using Cato to connect these plays (and them to the later The Man of the World) adumbrates the importance of history plays to eighteenth-century dramatists eager to politicize their work. History plays offered writers the capacity to present political critique as well as make intellectual claims through their deft command and re-presentation of historical narrative. Moreover, using the thread of Cato to make connections between history plays written over this period offers us a glimpse of an alternative Irish dramatic tradition that runs parallel to our typical interest, insofar as Irish playwrights are concerned, in comedies.

Cato was a touchstone for American patriotism, demonstrated by the famous performance staged by Washington in Valley Forge for his beleaguered troops in 1778; that the play also

\footnotetext{
${ }^{7}$ David O'Shaughnessy, 'Bit, by some mad whig': Charles Macklin and the Theater of Irish Enlightenment', Huntington Library Quarterly 80:4 (2017).
} 
proved a touchstone for Irish writers committed to political autonomy in the face of 'tyranny' should be unsurprising. The play's eponymous hero was particularly associated with Robert Molesworth (1656-1725), author of An Account of Denmark (1694), a seminal text in the Whig canon. As we have noted, Molesworth was a major Whig figure of the period. Such was the strength of Molesworth's reputation and his association with progressive Whiggism that he was also commonly assumed to be the author of Cato's Letters (1724), which, according to Blair Worden, was 'the principle depository of Republican ideas in the early eighteenth century' ${ }^{8}$ The provocative John Toland even produced election propaganda depicting Robert Molesworth as Cato. ${ }^{9}$ The play certainly resonated among Irish patriots of the 1710 s and 1720 s.

Lisa Freeman's analysis of the play helps explain the attraction of the play for these Irish. Cato, she argues, could not project the 'glories of an idealized Rome' onto England without also bringing into view the 'less than ideal politics' of its rise and its subsequent fall from power. Freeman sums up, 'If Rome were taken as the analog through which to project the future glory of England not only as a nation but as a burgeoning empire, the burden of history inexorably required an awareness of that empire's inevitable decline'. ${ }^{10}$ Laura Rosenthal's useful reading of the play puts Juba's enlightened cosmopolitanism front and centre and allows, as Daniel O'Quinn puts it, 'a consistent critique of Cato's tragic iconicity', and he illustrates how "certain audiences forgot about the tragedy of Cato to make "history" that strange attempt to figure forth a past that makes a future for life'. ${ }^{11}$ Irish patriots saw the

\footnotetext{
${ }^{8}$ The essays were published in almanacs from 1721. As it happens, it was, in fact, another graduate of Trinity College Dublin, John Trenchard, who co-authored them with Thomas Gordon.

${ }^{9}$ Robert Molesworth, An Account of Denmark, With Francogallia and Some Considerations for the Promoting of Agriculture and Employing the Poor, Edited and with an Introduction by Justin Champion (Indianapolis: Liberty Fund, 2011).

${ }^{10}$ Lisa Freeman, “What's Love Got to Do with Addison's Cato," SEL 39.3 (1999): 465.

${ }^{11}$ Laura J. Rosenthal, 'Juba's Roman Soul: Addison's Cato and Enlightenment Cosmopolitanism', Studies in the Literary Imagination 32 (1999): 64-75 and Daniel
} 
possibilities of Cato in re-presenting the Irish past in order to fashion future political agency. This re-presentation made claims of Celtic civility, honourable lineage, and organised systems of governance that predated colonialism; the subsequent alleged slide into violence and ignorance being blamed on repeated invasions. Thus the plays considered in this essay should be understood as emerging in dialogue with the historical revisionism of Irish writers from William Molyneux to Geoffrey Keating to Charles O'Conor, which also presented Ireland and the Irish as civilised before the debilitating destruction of invasion. ${ }^{12}$ Just as Cato's exploration of republican values takes place 'off-site' in North Africa, patriots present the treatment of Ireland as a proxy for the validity of Britain's imperial authority. Ultimately, as Rosenthal has deftly shown, to be Roman - that is, to adopt the ethical position of a virtuous Briton — 'demands the renegotiation of all other identity'. ${ }^{13}$ Successful Irish appropriations of the play then could disrupt pejorative historical justifications for British direct rule in a powerful and readily understood manner: Irish writers could prove themselves 'Roman' on a very public stage by writing historical dramas, the force of their writing augmented by the rich panoply of Irish actors working in the London theatres.

Remarkably, this most English of British plays is an illuminating example of the forceful Irish thespian presence. After the death of Barton Booth, the original Cato, in 1733, the role had a decidedly Irish flavour. Dennis Delane and James Quin were the primary actors of the part for many years in the London theatres. Quin, in particular, was dominant: he took the eponymous role for the first time on 18 January 1734 at Covent Garden and had three subsequent performances that season including on his benefit night. The following season he moved to Drury Lane where he played the part eight times (as it happens, Macklin killed

O'Quinn, 'Half-History, or The Function of Cato at the Present Time', Eighteenth-Century Fiction 27.3-4 (2015), 479-507: 486.

12 See introduction, 21-22.

${ }^{13}$ Rosenthal, 'Juba's Roman Soul', 70. 
Thomas Hallam on one of these nights). He continued as Cato at both major theatres up until his retirement in 1751. At the same time, Dennis Delane also played the part regularly at Goodman's Field, Drury Lane and Covent Garden in the 1730s and 1740s. The two Irishmen dominated the role in these decades: in the 85 performances of Cato documented in the London Stage between 1732 and 1745, the pair played the Roman hero on at least 66 of those occasions (some performances do not have cast lists so it is likely the actual figure is slightly higher). ${ }^{14}$ After Quin's retirement, the play seems to have lost some favour with the audiences and is performed much less often but Irish actors continued to feature nonetheless: Francis Gentleman in 1747 (1), Thomas Sheridan in 1754-55 (2) and 1760 (2), and Galwayman Henry Mossop in 1756-57 (4). In October 1775 Richard Brinsley Sheridan could write to Thomas Linley the Elder with pride that 'My father was astonishingly well received on Saturday night in Cato'. ${ }^{15}$ Irishness was imbricated in the performance of Addison's play through these various acts of surrogation from the 1730 s through to the 1770 s; the Irish actors playing Cato embodied the values of Whiggish constitutionalism during the mid-century for London audiences. James Quin even superintended the famous performance of Cato by members of the royal family in 1748. Jason Schaffer has argued that this royal performance was intended to show the public that the "requisite transmission of constitutional ideals and cultural 'Britishness' had taken place' within the German Hanoverian family; if an Irishman was entrusted with ensuring the success of this piece of royal propaganda, it is a powerful

\footnotetext{
${ }^{14}$ The London Stage 1660-1800, ed. Emmett L. Avery, Charles Beecher Hogan, William Van Lennep, Arthur Hawley Scouten, and George Winchester Stone, 5 parts, 11 vols. (Carbondale, IL: Southern Illinois University Press, 1960-68), part 3.

15 This was, the advertisement claimed, Sheridan's first appearance at Covent Garden in sixteen years. The Letters of Richard Brinsley Sheridan, ed. Cecil Price, 3 vols. (Oxford University Press, 1966), 1: 91.
} 
example of how the stock of the Irish had risen as well as indicating Quin's dominance of the role. $^{16}$

We will turn now to looking at how Cato materialized in the political theatre of Irish dramatists. As the introduction to this volume has suggested, the passage of the Declaratory Act in 1720 - an 'enslaving act' for Archbishop King - was particularly important in stoking up Irish oppositional politics. ${ }^{17}$ Swift's Proposal for the Universal Use of Irish Manufacture, first published in Dublin in 1720, is probably the best-known riposte to the Declaratory Act, the first in a series of acerbic pamphlets that would earn him his moniker as the 'father of Irish patriotism' ${ }^{18}$ Helen Burke has already shown how Dublin's Smock Alley Theatre was a prominent site of resistance and how Swift and Sheridan encouraged theatre audiences to 'wear Irish stuff' in an act of retaliatory economic intent. ${ }^{19}$ But responses also emerged from London-Dermod O'Conor's translation of Keating's Foras Feasa na hEireann being a significant example (see introduction, 21) - where the Irish were equally galvanized by the Declaratory Act. And theatre was also a crucial forum in London for such resistance.

Desmond Slowey rightly suggests that the Irish MP William Philips (d.1734) has not been adequately recognized for his patriot drama Hibernia Freed (1722). Philips was a Tory member of the Irish parliament between 1707 and 1711 and had previously had dramatic success in London and, notably, at Dublin's Smock Alley theatre with St Stephen's-Green; or, The Generous Lovers (1699), the first significant play to feature a Dublin setting. The incendiary Declaratory Act prompted the return of his dramatic impulse after more than a twenty-year gap.

\footnotetext{
${ }^{16}$ Jason Shaffer, 'Great Cato's Descendants': A Genealogy of Colonial Performance," Theater Survey 44 (2003): 5-28.

${ }^{17}$ Cited in Burke, Riotous Performances, 59.

${ }^{18}$ See Swift's Irish Writings: Selected Prose and Poetry, ed. Carole Fabricant and Robert Mahony (Basingstoke: Palgrave, 2010).

${ }^{19}$ Ibid., 53-83. See Colleen Taylor's essay in this volume on a later manifestation of the wearing of Irish 'stuff' as political gesture.
} 
The plot recounts an Irish victory over tyrannous Danish invaders at an unspecified, but evidently pre-Norman, epoch. It was enthusiastically received by the Lincoln's Inn Field's audience. The reviewer for the Freeholder's Journal for 21 February 1722 expressed surprise at the rapturous reception: 'I never knew a Play so Clapped, and must own I was a little Surprized, [...] till a Friend put me in Mind, that half the Audience were wild Irish', perhaps an indication of an emboldened Irish presence in London in the wake of the passage of the Declaratory Act. ${ }^{20}$ In his dedication Philips asked 'for what is so noble as to free ones Country from Tyranny and Invasion?'21 The play offers no simple equation of the English with the Danes but there are certainly veiled and pointed jibes made in the English direction. An early speech from the play's King O'Brien sets the tone:

Fertile Hibernia! Hospitable Land!

Is not allow'd to feed her Native Sons,

In vain they toil, and a-mid Plenty starve.

The lazy Dane grows wanton with our Stores,

Urges our Labour, and derides our Wants. (9)

Anyone with even the faintest knowledge of Irish politics could not have failed to pick up the references to trade, the issue identified by Swift (and indeed Molyneux before him) that would remain at the heart of Irish Protestant discontent for the rest of the century, right up to the Act of Union, as the chapters in this volume by Jones and Taylor testify. ${ }^{22}$ Rather than rejecting the principle of British rule, Philips asks for fair treatment, particularly

\footnotetext{
${ }^{20}$ London Stage, 2:1, clxiv.

${ }^{21}$ William Philips, Hibernia Freed, A Tragedy (London: Printed for Jonah Bowyer, 1722). Further references will be cited in the text by page number.

${ }^{22}$ For a useful treatment of the difficulties over trade, see the chapter on the eighteenth century in Thomas Bartlett, Ireland: A History (Cambridge University Press, 2011).
} 
in commercial matters, as well as for internal political autonomy. The play's conclusion simultaneously accepts the principle of British rule while challenging the empire to live up to its supposed precepts: the final scene sees the defeated Turgesius of Denmark deliver a dark prophecy that is subsequently turned on its head by Eugenius, bard and chief adviser to O’Brien:

Turgesius: But e'er I part, remember I foretell, Another Nation shall revenge my Death, And with successful Armes invade this Realm.

$[\ldots]$

Eugenius: Another Nation shall indeed succeed,

But different far in Manners from the Dane, (So Heav'n inspires and urges me to speak) Another Nation, famous through the World, For martial Deeds, for Strength and Skill in Arms, Belov'd and blest for their Humanity.<smiles>C1[AlH][AlH]1</smiles>

And mix their Blood with ours; one People grow, Polish our Manners, and improve our Minds.

This pointed conclusion underlines a central aspect of the Irish patriot movement: the demand for political autonomy did not imply a separation from Britain. Irish patriots largely insisted on Ireland as a separate kingdom — with all its associated institutional trimmings — but tied to Britain under the authority of the monarch and this would remain true right through the 
century. ${ }^{23}$ In a drama where the Irish characters have displayed virtue, self-restraint, and reason throughout, Eugenius' closing speech asks the audience to consider the appropriateness of the Declaratory Act, given what they have just witnessed.

Philips's forthright challenge to external regulation of the Irish people seems to have met with approval from the audience - judging by the newspaper report cited above at leastand it played for a respectable six nights in February, finishing off with a seventh performance on St Patrick's Day. The Irish characters of Hibernia Freed demonstrate time and time again their capacity for virtue, their privileging of reason, and their inherent civility. O'Brien bemoans the condition of 'Hibernia! Seat of Learning! School of Science!' (9) and declares 'Reason is our guide [...] Reason directs us to the Choice of Good' (35). Slowey's analysis shows how the play details 'an ancient Irish society displaying both the neo-stoic virtues of the Enlightenment and a civilization equal to ancient Greece and Rome' ${ }^{24}$ But we may be more specific, it seems, given the prominence of Molesworth among 1720s London Whigs. The emphasis laid on reason in the play is particularly pronounced and, juxtaposed against the venal Danes, makes clear that Phillips is aligning his drama with Molesworth's Account of Denmark and thus investing the Irish with those values of liberty and reason lauded in that text. Hibernia Freed was staged at a moment in London when the origins of the Irish nation were being replotted in a new history, the national character of its people was being reimagined on and offstage, and when vocal patriot arguments were being made as to Ireland's right to economic and political self-determination in all sorts of forums. It would be rather surprising if elements of Addison's masterpiece, the most well-known play about political freedom and resistance, were not found in Philips's play.

\footnotetext{
${ }^{23}$ Stephen Small, Political Thought in Ireland 1776-1798 (Oxford University Press, 2012). For a later example of this tradition with a theatrical connection, see playwright Leonard MacNally's The Claims of Ireland (London, 1782).

${ }^{24}$ Desmond Slowey, The Radicalization of Irish Drama, 1600-1900 (Dublin: Irish Academic Press, 2008), 113.
} 
Hibernia Freed echoes many elements of Cato. That O'Brien's son is named Lucius, the name of a loyal senator to Cato, is immediately striking but there are other echoes of the play such as Irish warrior Herimon's celebration of his sons' martial deaths: 'Five Sons I once cou'd boast, and in their Death / I Glory still. For you, for Liberty / They fell' (13); his daughter Agnes's rebuke of O'Connor's lovemaking 'And hast thou Leisure to reflect on Love? / Just on the verge of Death; nay worse, our Lives / Depending on the Favour of the Danes' (15) invokes Marcia's slapdown of Lucius 'wouldst thou have me sink away / In pleasing dreams, and lose myself in love, / When every moment Cato's life's at stake? ${ }^{25}$ Throughout the play Turgesius' 'wild ambition' or 'vain ambition' is castigated just as Caesar's ambition is repeatedly assaulted in Cato, right from the prologue. ${ }^{26}$ More generally speaking, there is a disciplined martial virtue as well as a chaste self-restraint in sexual matters in the Irish that aligns them with the republican Romans of Cato rather than the popish subservience of Catholic Rome. This capacity for principled and courageous selfregulation distinguishes them from the lustful, savagely violent and power-hungry invaders of the play.

But there are some important variations in Philips's drama, particularly in his rejection of Cato's suicide, a nodal point of critical importance. Rosenthal has shown how Cato should be understood as an extreme rather than an exemplar. ${ }^{27}$ Hibernia Freed, despite its generic nomination as a tragedy, shies away from any act of self-destruction by the Irish

\footnotetext{
${ }^{25}$ Joseph Addison, Cato: A Tragedy and Selected Essays, ed. Christopher Dunn Henderson and Mark E. Yellin (Indianapolis: Liberty Fund, 2011), I.vi:10-12. Further references will be cited in the text by act, scene and line number.

${ }^{26}$ See also 'wild ambition well deserves its woe' (Prologue, 11); Portius to Marcus 'Ye gods, what havoc does ambition make / Among your works!' (I.i.10-11); Sempronius bemoans the 'bars to his ambition' presented by Cato (I.iii.54); and Cato cries 'Oh curst ambition!' (IV.iv.103).

${ }^{27}$ Rosenthal, 'Juba’s Roman soul', 65-66.
} 
characters. ${ }^{28}$ Evidently, the prospect of presenting a London audience with an Irish king prepared to kill himself before political subjugation was far too hardnosed a position and one that would not be commensurate with the general tenour of Irish patriotism. Indeed, at one point O'Brien advocates a pragmatic acceptance of the situation that is far removed from both Cato's rigid defiance and the traditional characterization of the Irish being prone to frenzied violence:

The Loss of Empire and the Loss of Pow'r

We may support, while Reason is our guide.

Better be subject to the Danes, than as

This Dane, to ev'ry Passion be a Slave. (35)

These lines are rather extraordinary in their apparent acquiescence to servitude. Yet for Philips, despite the undoubted strength of his feelings on the inequities of the Declaratory Act and its reaffirmation of economic and political subjugation, it was more important to signal an ethnic disdain for untrammelled violence. There is a dignity to O'Brien in these lines which express his Enlightenment preference for individual and rational self-discipline and a sense that national pride cannot countenance such moral degradation. Enlightenment, it seems, is a process that requires patience and a willingness to embrace indignities for the greater scheme. Irish civility must be presented and maintained above all other considerations.

${ }^{28}$ The tragedy, it would appear by the play's satisfying conclusion for the Irish, is displaced offstage to the current political and economic woes of Ireland. 
If in 1739 James Quin had actually played the title role of Gustavus Vasa as was intended by Henry Brooke - who hailed from Cavan - the connection with Cato would have been made more obvious. ${ }^{29}$ Brooke claimed that British values of liberty and love of country motivated Gustavus Vasa; claims that did not prevent it from becoming the first play to be refused a licence under the Stage Licensing Act (1737). Commentators such as L. W. Conolly and Herbert Wright are agreed that the play, in particular the venal courtier Trollio, is a blatant attack on Walpole and his corrupt premiership. ${ }^{30}$ However, the influence of Cato on Brooke has not been fully acknowledged. Gustavus, after all, in a nod to Molesworth, was resisting Danish invaders and we know that Brooke, a friend of Swift, later imagined himself as a Cato figure in retirement. When Brooke had returned to Ireland, a visitor found these carefully transcribed lines - handwritten 'in imitation of print' - from Cato in Brooke's house:

Let me advise thee to retreat by times

To thy paternal seat, the Sabine field,

Where the great censor toil'd with his own hands,

And all our frugal ancestors were blest

In humble virtues, and a rural life.

There live retir'd, pray for the peace of Rome,

Content thyself to be obscurely good. ${ }^{31}$

${ }^{29}$ Herbert Wright, 'Henry Brooke's 'Gustavus Vasa', Modern Language Review 14 (1919): 173-82, 177.

${ }^{30}$ L. W. Conolly, The Censorship of English Drama, 1737-1824 (San Marino: Huntington Library Press, 1976), 54-56 and Wright, 'Henry Brooke's 'Gustavus Vasa', 176.

${ }^{31}$ C. H. Wilson, Brookiana, 2 vols. (London: Richard Philips, 1804), 2: 83. 
Turning to the play itself, Gustavus Vasa's love of country and willingness to make personal sacrifice make the play's debt to Cato quite clear. Brooke's preface_-an indignant protest against the decision of the refusal to licence the drama - makes much of the play's championing of patriotism and personal freedom: 'By Personal Freedom I mean that State resulting from Virtue; or Reason ruling in the Breast superior to Appetite and Passion'. ${ }^{32}$ The prologue even makes explicit references to Caesar:

Such, such, of old, the first-born Natives were, Who breath'd the Vertues of Britannia's Air, Their Realm, when mighty Caesar vainly sought; For mightier Freedom against Caesar fought, And rudely drove the fam'd Invader Home, To tyrannize o'er polish'd— - venal Rome.

Other themes found in Cato are also present. The implication that love 'Degrades the Hero, and makes Cowards valiant' (20) echoes Cato's scepticism towards romantic love and its debilitating effect on patriotic virtue. Cristina, the daughter of the usurper, recounts how she was offered up to Gustavus by way of appeasement, but he turned her down. Like Cato, Brookes's play is scathing of personal ambition; Cristina observes:

What's all the gaudy Glitter of a Crown?

What, but the glaring Meteor of Ambition

That leads a Wretch beighted in his Errors,

${ }^{32}$ Henry Brooke, Gustavus Vasa, The Deliverer of his Country, A Tragedy (London: Printed for J. Buck, 1739). Further references will be cited in the text by page number. 
Points to the Gulph, and shines upon Destruction (25)

At the close of the play, Cristina's sublimation of personal desire to paternal duty at the brings both Lucia and Marcia from Cato to mind. The debt to Addison is quite clear but the play also demonstrates how the discourses of Irish patriotism and English Whiggism could overlap in productive ways. Drawing on Cato, Brooke was able to make clear his adherence to those British values of liberty and personal freedom while also suggesting that the case of Ireland demanded that those values should also be equally applicable to Protestant Ireland. That Brooke set his opening scene, where Swedish nobles meet to outline the necessity of their patriotic revolution and where Gustavus reveals himself to them, in a copper mine leaves his political intentions in little doubt. The charge led by his friend Jonathan Swift on the Wood's ha'pence affair — concerning the feared introduction of debased copper currency into Ireland - is explicitly referenced. The pamphlets composed by Swift in 1724 attacking this British policy were even signed M. B. Drapier, Marcus Brutus being one of the antityrannical republicans that assassinated Caesar and who, like Cato, later committed suicide. ${ }^{33}$ Critics understood his Irish patriot intentions. One commentator produced a vitriolic scene-by-scene hatchet job of the play and repeatedly brought up its Irish traits, wondering of the scene in the copper mines whether it was to have been painted by 'Patrick Mac ma-hone', mocking another scene 'By my Shoul that was charmin!', and suggesting that the author adopt some 'new coin'd Irish words that seem'd strangely expressive' ${ }^{34}$ The criticisms might be thought to attack the author's Irish nationality rather than any purported Irish patriot reading of the play itself but the critic makes a comparison between the Dalecarlians - that is, the people of an 'off-site' Swedish region whom Gustavus Vasa stirs to action-and the

\footnotetext{
${ }^{33}$ On the Wood's halfpence affair, see Swift's Irish Writings, ed. Fabricant and Mahony.

${ }^{34}$ The Country Correspondent: Humbly addres'd to Gustavus Vasa, Esq (London: Printed for R. Swan, 1739), 13, 19, 21.
} 
'Wild Irish' ${ }^{35}$ The critical scene in which Gustavus, through the force of his principled rhetoric stirs them to action is labelled 'dull Hibernian Stuff' and hence suggests that Gustavus's speeches exhorting love of country were read as offering a critique of colonial rule of Ireland..$^{36}$ The Dalecarlians are described in terms evoking primitivist accounts of Celtic purity:

A Race of hardy, northern Sons he led, Guiltless of Courts, untainted, and unread, Whose inborn Spirit spurn'd th'ignoble Fee, Whose Hands scorn'd Bondage, for their Hearts were free (Prologue, n.p.)

Recently returned to London after a stint of eight years in Ireland, Brooke was an outside observer, keen to reform the centre of governance. Gustavus Vasa places itself within the Cato tradition with Brooke suggesting his Irishness is an asset, capable of highlighting the fall from idealist grace of British politics. It is an apposite coincidence-but likely no morethat Brooke's letter of protest regarding the prohibition of his play appeared on 17 March in the Daily Post. ${ }^{37}$ Publishing his letter on St Patrick's Day may have appeared to be a calculated gesture to align the play with Irish patriotism, certainly it left itself open to be understood in that way. When the play was performed in Dublin in 1742 as The Patriot - the

\footnotetext{
${ }^{35}$ Ibid., 23.

${ }^{36}$ Ibid., 28.

${ }^{37}$ Indignant, Brooke explained how William Chetwynd, the Examiner, had not only declined to issue a licence but had also refused to explain his decision. 'The Author', concluded Brooke, 'apprehending that he is greatly aggriev'd, in order to repair the Damages he hath sustain'd, proposes to print the said Play by Subscription, on Royal Paper, at Five Shillings each Copy, and humbly hopes the Encouragement of every impartial Lover of Virtue and Liberty', Daily Post, 17 March 1737.
} 
city not being subject to the Stage Licensing Act — it was received with considerable applause as it was read as an attack on British rule. ${ }^{38}$

We turn now to our final example, Charles Macklin's King Henry the VII; or, The Popish Impostor (1746). ${ }^{39}$ Macklin wrote Henry the VII partly as a public declaration of loyalty to the Protestant Hanoverian regime: that much seems self-evident. Although Ireland itself was sufficiently docile that Dublin Castle could send troops to Scotland, the proximity of Jacobite forces - which came within 130 miles of London in 1745-made for anxious times in the capital for the Irish, as noted by Ian Gilmour. ${ }^{40}$ As an Irishman who struggled with mockery of his Donegal accent; as a convict found guilty of manslaughter in a high profile case in 1734; and, as an actor who had terrified theatregoers with his snarling Shylock, it is fair comment to say that Macklin had more cause to be concerned than others. ${ }^{41}$ Moreover, he had only recently returned to the stage in December 1744 after a well-publicized feud with David Garrick that had left him isolated from his fellow actors and with a further reputation for dispute. ${ }^{42}$ Perhaps a need for some good publicity was what fuelled the hasty six-week

\footnotetext{
${ }^{38}$ Helen Burke, Riotous Performances, 122-23.

${ }^{39}$ Charles Macklin, King Henry the VII. Or The Popish Impostor (London: Printed for R. Francklin et al, 1746). Further references will be to the Larpent manuscript, titled The Alternative, Tyranny or Liberty, by folio number. Huntington Library, Larpent MSS, LA 55. ${ }^{40}$ Ian Gilmour, Riot, Risings and Revolution (1992), 118. Irish Catholics, of course, had long been associated with the nefarious Jacobite agenda, stretching back in recent memory to the Popish Plot of the late 1670s. Pamphlets citing supposed examples of Irish barbarism and violence in the 1641 Rebellion also emerged at this time. See, for example, Popery and Slavery Display'd (London: C. Corbett et al, 1745); The Bloody Cruelties of the Papists against the Protestants (London: J. Lewis, 1745), and A Brief Account of the Methods used to Propagate Popery (London: J. Oldcastle, 1746).

${ }^{41}$ See Emily Anderson, 'Celebrity Shylock', PMLA 126.4 (2011): 935-49, 940-42.

${ }^{42}$ See William W. Appleton, Charles Macklin: An Actor's Life (Boston, MA: Harvard University Press, 1960), 56-65.
} 
composition of his tragedy about Perkin Warbeck, the rebellious fifteenth-century Pretender.

Staged on 18 January 1746 at Drury Lane, the play's prologue_-delivered by Macklin

himself in character as the Scottish noble Huntley_made a clear statement on his loyalties:

When Popish Rage, \& Persecution blaz'd

And Britons bled on Altars Rome had rais'd;

When Matrons saw their Sons in Flames expire

And Husbands crackling in religious Fire,

Then Rome gave laws; our Kings \& Council sway'd

While Briton mourn'd her Liberties betray'd.

But now she smiles, the Laws are all her own,

And rule alike the Cottage $\&$ the Throne. (n. f.)

However, it was a dismal failure. A gleeful Tobias Smollett jibed in Roderick Random, that the play 'by the strength of art, lingred [sic] till the third night, and then died in a deplorable manner'.${ }^{43}$ Susannah Cibber called it 'much below anything I ever yet saw'. ${ }^{44}$ Consequently, it has received scant critical attention with Michael Wagoner producing the fullest account and explication of its failure to date. ${ }^{45}$ On examination, however, the play's Larpent manuscript suggests a more complicated drama than that previously acknowledged.

\footnotetext{
${ }^{43}$ Tobias Smollett, The Adventures of Roderick Random, ed. O. M. Brack with an introduction and notes by James G. Basker, Paul-Gabriel Boucé and Nicole A. Seary (Athens and London: University of Georgia Press, 2012), 332. Smollett, a sufficiently brave Scottish nationalist to publish sympathetic poetry regarding Culloden in 1746, was presumably provoked to the jibe by Macklin's depiction of his countrymen.

${ }^{44}$ Cibber to Garrick, cited in Appleton, 76.

${ }^{45}$ Michael M. Wagoner, 'The 'Merry' Tragedy of Henry VII as written by 'Charles Macklin, Comedian', New Theatre Quarterly 31.4 (2015), 372-80. Wagoner suggests that the dissonance between Macklin's reputation as a comic actor and the play's serious tone provoked the harsh audience reaction.
} 
Despite Macklin's apparent ringing endorsement of the Hanover regime, the manuscript is marked in various places with small ' $\mathrm{x}$ 's in a manner consistent with other emendations probably made by Thomas Odell, then Deputy Examiner. Looking at these interventions collectively, we observe that the lines marked for omission chiefly pertain to Huntley, the virtuous noble played by Macklin, and they refer to matters of kingly governance. One example will give a flavour of what excited Odell's attention: this is Huntley on the respect — determinedly equivocal, it seems - due to monarchical authority:

The People's Interest,

In free Nations is blended \& Coequal

With $y^{\mathrm{e}}$ Kings, \& he who separates or

Over values either is the Traitor

[... $\quad$ when defiled

By Tyranny \& PriestCraft, [majesty] becomes

A Magazine of Vengeance, \& all our

Veneration turns to Contempt \& Wrath ${ }^{46}$ (f.45r)

Macklin certainly extols the excellence of Protestant liberty in opposition to the slavish obedience associated with Catholicism; but he is also keen to offer a broader and constructive critique of British political life. His Whiggish references to countering mendacious courtiers, his criticism of the stagnancy of the body politic, and, his demarcation of the limits of kingly authority that irked Odell are important elements, I have elsewhere argued, that help facilitate

\footnotetext{
${ }^{46}$ Other examples of passages marked unfit for representation include Huntley observing that 'Council void of Freedom may flatter and / Mislead but never can assist' (f.7r); 'I see Majesty - Deluded Majesty, / Hem'd in by a Band of crawling Parasites' (f.7v); 'the Interest of Court now / Is who bids the most' (f.10r); and, 'gracious Sir, let Reason School / Y ${ }^{\mathrm{r}}$ Youthful distemper'd Heat \& Sound Judgm ${ }^{t}$ (f.44r).
} 
a reading of Macklin's later and more successful comedies as considered political commentary rather than surly ethnic ripostes to prejudice. ${ }^{47}$ While one could argue that the Examiner's interventions are as much a reflection of the then political volatility as any intent of overt political intervention on Macklin's part, the censored lines have an explicitly patriot flavour and alert us to its resonance with Hibernia Freed and Gustavus Vasa.

Macklin's play has strong whiffs of Whiggery with the play's determined critique of 'ambition' and great men, an abhorrence of corrupt courtiers, and, tellingly, a marked insistence on the virtue of commerce throughout — the play ends with Henry declaring 'Let Faction cease, Commerce \& freedom smile / The World can't Conquer then, this War-proof Isle' (f.58r). Building on Brooke, trade and commerce are put front and centre of a play that underlines how Whiggish principles and Irish patriotism overlap in powerful ways that would persist through the rest of the century. ${ }^{48}$ There are also distinct echoes of Cato; however, as I have previously documented these, I shall eschew working through them in favour of building a larger argument. ${ }^{49}$

The introduction to this volume has placed Macklin as the heartbeat of the Irish theatrical Enlightenment with his performance as Shylock at a particularly potent moment for the London Irish theatrical world, signifying all sorts of possibilities for Irish success in the sphere of culture. As I work towards a conclusion here, I want to show how this playdespite its undoubted commercial failure - reveals an intellectual and political ambition that strengthens his case to be considered as the pivotal figure within Irish circles in the 1740s. By this mid-century point, London has more Irish playwrights emboldened by growing patriot sentiment, increasing numbers of middle-class Irish migrants, a more pronounced Irish acting

${ }^{47}$ O'Shaughnessy, “'Bit, by some mad whig'.

${ }^{48}$ For an illuminating later example, see playwright Leonard MacNally's pamphlet The Claims of Ireland (London: J. Johnson, 1782).

${ }^{49}$ See O'Shaughnessy, 'Bit, by some mad whig', 579-81. 
presence in the theatres, all in a city where there was a growing culture of tolerance on the part of the English, particularly as Scottophobia spread. Macklin's play, I will argue in what follows, is also an act of emboldened Irish historical revisionism that evidences a third layer of political ideology on top of the profession of Hanoverian loyalty and his proclamation of Whiggish values.

Henry the VII is a reworking of John Ford's Perkin Warbeck (1634). Although Ford's play was described by T.S. Eliot as 'almost flawless', the eighteenth century took a dimmer view, there being no record of its performance in the theatrical calendar. ${ }^{50}$ Macklin's decision to go with a reworking of this play then seems immediately bold and ambitious, another attempt to restore a play to the canon as he had with The Merchant of Venice. Moreover, it offered a more sober response to the rebellion than the jeering of Cibber's The Non-Juror or Fielding's The Old Debauchees. By comparing Ford's and Macklin's versions of the Perkin Warbeck story we can advance this argument. First, however, a brief sketch of the history dramatized in both plays is necessary.

Lambert Simnel (b. 1476/7 - after 1534) was an earlier pretender to the throne from the late $1480 \mathrm{~s}$. The full story of his attempt to take the throne need not detain us long, suffice to say that the city of Dublin and various Irish supporters such as the earl of Kildare, disaffected by Henry II's reign, gave significant support to Simnel's claim to be the heir of George, duke of Clarence. Indeed, Simnel was actually crowned king of England in 1487 in Christ Church Cathedral in Dublin, prompting Henry to comment that the Irish were so foolish that they would someday crown an ape. A subsequent invasion of England, supported by German mercenaries and 4000 Irish troops, ended in dismal failure in 1487. Simnel entered Henry's service as a scullion and later a falconer; he was considered useful

${ }^{50}$ Perkin Warbeck in John Ford, 'Tis Pity She's A Whore and other plays, ed. Marion Lomax (Oxford and New York: Oxford World's Classics, 1995), xxi. Further references will be cited in the text by act, scene and line number. 
propaganda and was supposed to have been once presented to Irish lords on a visit to court to remind them of their past foolishness.

A few years later, Perkin Warbeck was also recruited to the Yorkist cause while he was visiting Ireland. In 1491 he was persuaded by Fryon, a Burgundian diplomat and spy; the former mayor of Cork, John Atwater; and others to adopt the guise of Richard, second son of Edward IV and one of the princes in the tower. After his time in Cork, Warbeck gained some support in France, Vienna, and England before an attempt to invade England ended disastrously without even disembarkation in 1495. His flotilla moved on to Ireland where he tried unsuccessfully to take Waterford before finding succour at the court of King James IV in Scotland. James married him to Katherine Gordon, daughter of the earl of Huntley, as a demonstration of support. An invasion of England found few allies south of the border and Ireland remained quiet under the now obedient earl of Kildare. Rebels in Cornwall offered significant assistance, but the game was up by 1498 and his execution followed a year later. There were no more vacancies, it would appear, in the royal kitchenError! Not a valid

\section{bookmark self-reference.Error! Not a valid bookmark self-reference..}

In Ford's play, the opening scene has Lord Chamberlain Stanley insist to Henry that the memory of Simnel and others - including the Earl of Kildare - would be enough to deter conspirators as they are 'Most spectacles of ruin, some of mercy_' (I.i.95) Throughout his play there are pejorative references to the Irish: ‘th'superstitious Irish' (I.iii.39). When Henry suspects that 'Some Irish heads work in this mine of treason' Clifford responds:

Not any of the best; your fortune

Hath dulled their spleens. Never had counterfeit

Such a confused rabble of lost bankrupts

For counsellors; first, Heron, a broken mercer, 
Then John A-Water, sometimes Mayor of Cork

Sketon, a tailor, and a scrivener

Called Astley (I.iii.55-61)

Later, Frion tricks the foolish Irish contingent into making an 'Irish hubbub (II.iii.165) at the wedding, provoking them by suggesting the Scots would take all the glory if they did not perform. The wedding masque stage direction-Enter at one door four Scotch Antics, accordingly habited; enter at another four wild Irish in trousers, long-haired, and accordingly habited - gives us both a clear indication of the visual comic force of the Other offered by the Celts as well as Ford's easy and uncritical conflation of Irish and Scots. After the Irish leave the wedding, Frion complains of having to deal with their idiocy:

O, the toil

Of humouring this abject scum of mankind!

Muddy brained peasants! (II.iii. 176-8)

In Ford's tragedy, Ireland features throughout as a source of dissent, rebellion, barbarism, and stupidity. The character John A-Waters is very much a Stage Irishman, uttering nonsensical Irish bulls to Henry after he is caught, and he is easily manipulated by the wily Frion. Ireland is associated with both Simnel and Warbeck and the casual association with Scotland offers it little in terms of distinguishing itself from this other Celtic nation.

As one might imagine, the Irish were very keen to distinguish themselves from Scotland after $1745 .{ }^{51}$ Just as Ireland had remained pacified in 1715 , this was also true in

${ }^{51}$ Charles O'Conor would continue to make this point (on Irish pacifity vs Scottish aggression in 1745) in the London press of the early 1760s. O'Shaughnessy, 'Bit, by some mad whig', 569. 
1745. And if we look at Macklin's play, this is borne out very clearly. There is no John AWaters or any Irish character in the play which is fixedly targeted at Scottish perfidy. The opening scene has characters Frion and Sevez (his priestly master conspirator) meet in Holyrood Palace. Thus the story starts in Scotland and the Irish episodes with Simnel and Warbeck are cut from the story. And the lines between Ireland and Scotland are drawn early: Sevez notes the fact that their forces 'Abound in Scottish blood / Ready to be drain'd against England's peace' before asking 'But how / Stands Ireland? What Hopes from thence?' (f.1v) Frion responds:

\section{None}

Th'Apostate Slaves are fall'n off from Rome

And firmly fixt in the Usurper's Cause

Kildare, Clanrikard with many others

On whom we built Absolute Assurance.

Have, at their own Charge, arm'd their Friends \& followers, And joind the English General, Poinings (ff.1v-2r)

Ford's traitorous Kildare has now become the loyal supporter aligned seamlessly with English military forces at his own expense, his awkward historic treason expunged from the record. Moreover, Frion goes on to point out at length the extent of English treason; the danger from within is offered as being deeply problematic.

Paddy Bullard has recently argued that an emphasis on public speaking and oratory distinguishes Irish approaches to rhetoric in the eighteenth-century. Molesworth, Swift, Berkeley and others all worried about a perceived failure of civic eloquence and Bullard offers Sheridan's 'Hibernian Academy', a 1757 initiative which proposed a patriot 
educational system based on elocution as a response to such concerns. ${ }^{52}$ But the history play tradition traced here of Philips, Brooke, and Macklin might also be seen as 'praxis as response' that demonstrated both the capacity of the Irish to fashion and articulate an Irish political future in harmony with British values whilst simultaneously demanding a moderate degree of autonomy. In Macklin's Henry the VII, the alliance of Poinings with Kildare signals the acceptance of British norms while the implications of Huntley's Catoesque rhetoric, the character written and played by Macklin, are that Britain should clean its own political Augean stable and extend its much vaunted 'liberty' to the Irish. While Philips and Brooke look to the ancient past and the European other to frame their allegories, Macklin's insistence on tackling relatively recent British history_-and limiting the historical distance between audience and object of historical enquiry — represents a heightened assertiveness in the Irish position, one that was emerging in an equally bold Irish historiography of the midcentury led by leading Irish Catholic intellectual Charles O'Conor, a historiography that was keen to advance beyond Keating. ${ }^{53}$ We might also reflect that the cast of Macklin's drama included Macklin, Margaret Woffington, Dennis Delane, and William Havard, providing a telling synecdoche for the collective affective force of Irish actors during the long eighteenth century in London which could be capitalized upon by dramatists.

Henry the VII may have been a failure but it is an illuminating drama that opens an alternative perspective on the eighteenth-century Irish theatrical tradition, too often reduced to comedies. There is value in looking beyond She Stoops to Conquer and The School for Scandal to thicken our understanding of the Irish contribution to London's cultural life as

\footnotetext{
${ }^{52}$ Paddy Bullard, 'Rhetoric and Eloquence: The Language of Persuasion' in The Oxford Handbook of British Philosophy in the Eighteenth-Century, ed. James Harris (Oxford University Press, 2014), 89.

${ }^{53}$ Other notable revisionists include John Curry and Sylvester O'Halloran. See, for example, O'Halloran, Golden Ages and Barbarous Nations and Charles O'Conor of Ballinagare, ed. Gibbons and O'Conor.
} 
well as our understanding of how the political and theatrical worlds interacted. Historical drama is a form of re-enactment: Mark Salber Phillips has recently defended re-enactment's affective tendencies on the grounds that affect itself has cognitive implications. ${ }^{54}$ It is a participatory mode of historical enquiry in which spectators, ultimately, have something of an ethical imperative to measure, assess, and judge. In an age of sympathy, the collective Irish investment in historical enquiry, both on stage and off, speaks to a growing assurance on their part, increased tolerance on the part of their English audience, and, most tellingly, a determination on the part of the Irish diaspora to signal their cultural assimilation and as well as their capacity to advance understanding and knowledge.

Irish dramatists such as Macklin saw historical drama as the mechanism by which they could connect themselves to an extant literary tradition, announce themselves as serious participants in political debate, as well as make explicit the rich contribution Irish writers could make to British intellectual life. A new genealogy of Irish theatre of the eighteenth century would include, for instance, William Havard's Charles I (1737), Elizabeth Griffith's Theodorick, King of Denmark (1752), Robert Jephson's Braganza (1775), Leonard MacNally's Robin Hood (1784), Thomas Stratford's Lord Russell (1784), not to mention history plays produced by John O’Keeffe, Frederick Pilon, James Sheridan Knowles, and Arthur Murphy to name but a few. What would happen, for instance, if we looked at Oliver Goldsmith's little known oratorio The Captivity (1763) as a history play and read this story of resistance to Egyptian tyranny by a landless Jewish people through the lens of Irish patriotism and its historiography, which often drew comparisons between the Irish and Jewish peoples? How might this perspective alter our sense of his politics? Equally, how would our sense of his canon shift?

\footnotetext{
${ }^{54}$ Mark Salber Phillips, 'Introduction: Rethinking Historical Distance' in Rethinking Historical Distance, ed. Mark Salber Phillips, Barbara Caine and Julia Adeney Thomas (Basingstoke: Palgrave, 2013), 12.
} 
Collectively, these various plays represent an important facet of eighteenth-century Irish patriotism: the determination of a people to tell their own history with a view to achieving political autonomy. These interconnected history plays and their engagement with political thought bolster the idea that, as Ian McBride has suggested, theatre is one of the unexamined institutional structures of the Irish Enlightenment. ${ }^{55}$

The Goldsmith example shows the necessity of fully theorizing the genre to advance critical discussion, and not just for Irish writers. When we start to look, we can see that many writers of the century wrote or attempted to write history plays: James Miller and John Hoadly (Mahomet [the Impostor], 1744); Samuel Johnson (Irene, 1749); William Whitehead (The Roman Father, 1750); Richard Cumberland, The Banishment of Cicero (1761); William Blake (King Edward the Third, 1783); Ann Yearsley (Earl Goodwin, 1789); William Godwin (St Dunstan, 1790), Samuel Taylor Coleridge (The Fall of Robespierre, 1794); Frances Burney (Edwy and Elgiva, 1795); and Percy Shelley (Charles I, 1822). Even from this brief selection, we can make some initial generalizations that provoke enticing questions: why do so many writers try to write a history play for their first dramatic venture in the supposed age of comedy? Why is there such a high degree of failure and incompleteness? And why was the history play genre so politically contentious (as well as the first three plays prohibited, many later history plays were refused licences)? These are worthwhile questions for the eighteenth-century theatre historian. Paine's famous rebuke of Burke - that he should remember he was writing history, not plays - is not simply a reprimand for his florid style; Paine betrays his anxiety regarding Burke harnessing the affective and intellectual force of the history play, the neglected genre of the Georgian London stage.

${ }^{55}$ Ian McBride, 'The edge of Enlightenment: Ireland and Scotland in the eighteenth century', Modern Intellectual History 10 (2013): 147-48. 